\title{
Effect of Structural/Content Career Plateaus on Job Involvement: Do Institutional/Occupational Intentions Matter?
}

\author{
Tzu-Wei Su ${ }^{1}$, Jyh-Huei Kuo ${ }^{2}$, Yu-Ha Cheung ${ }^{3}$, Cheng-Ze Hung ${ }^{1}$, Shih-Hao Lu ${ }^{4}$, Jen-Wei Cheng,"* \\ ${ }^{1}$ Department of Business Administration, National Taiwan University of Science and Technology, Taiwan \\ ${ }^{2}$ Department of Business Administration, National Taipei University, Taiwan \\ ${ }^{3}$ Department of Management, Hong Kong Baptist University, China \\ ${ }^{4}$ Department of Supply Chain and Information Systems, Iowa state University, USA
}

Copyright $\subseteq 2017$ by authors, all rights reserved. Authors agree that this article remains permanently open access under the terms of the Creative Commons Attribution License 4.0 International License

\begin{abstract}
This study examined the potential moderating roles of career officer's institutional intention and occupational intention on the relationship between structural/content career plateaus and job involvement in Taiwanese career military officers. Empirical data were collected from 338 career officers who received full-time training at the National Defense University in Taiwan. The results showed that the perception of structural/content career plateaus were both negatively related to job involvement. Furthermore, the results found the supports of the moderating role of institutional intention in the relationship between perceived structural/content career plateaus and job involvement, and the moderating role of occupational intention in the relationship between perceived structural career plateau and job involvement. Practical management and research implications are discussed, and future research directions suggested.
\end{abstract}

Keywords Structural/Content Career Plateaus, Career Plateauing, Institutional/Occupational Intentions, Job Involvement

\section{Background}

Previous literature has documented that plateau employees are more likely to report low organizational identification, high turnover intention [27], low work satisfaction, low effective, and low continuous commitment [17], and less involvement in their work [10]. Hobfoll, Vinokur, Pierce, \& Lewandowski-Romps [8] suggested that career plateauing is a source of stress for employees, thus, reducing their job involvement. Although career plateauing has received substantive research attention in civilian organizational settings, little is known in the Taiwan military setting. From a practical perspective, considering the vast number of personnel involved and the increasing pressure to enhance performance in response to the intensification of geopolitical tension, military organizations need to understand how senior officers' perception of career plateau may adversely affect their job involvement. More importantly, we seek to understand whether certain individual differences would mitigate the adverse effect of career plateau on job involvement. Drawing on Mosko's [14] and Cheng \& Su [5] institutional and occupational model of military careers, we examined the potential moderating roles of career officer's institutional intention and occupational intention on the relationship between structural/content career plateaus and job involvement.

Military service has traditionally been deemed a calling or vocation [6]. The institutional model posits that the military service is a calling, whereas the occupational model is based on a contract that defines the rights and responsibilities of employers and employees. Military personnel with an institutional orientation are highly committed to their pledge to the nation, duty, and honor, hold the belief that military life should reflect norms of high primacy, and accept more pervasive institutional controls over their behavior, both on and off duty [16]. As military personnel become increasingly occupationally oriented, their potential negative responses to organizational change require special attentions. 


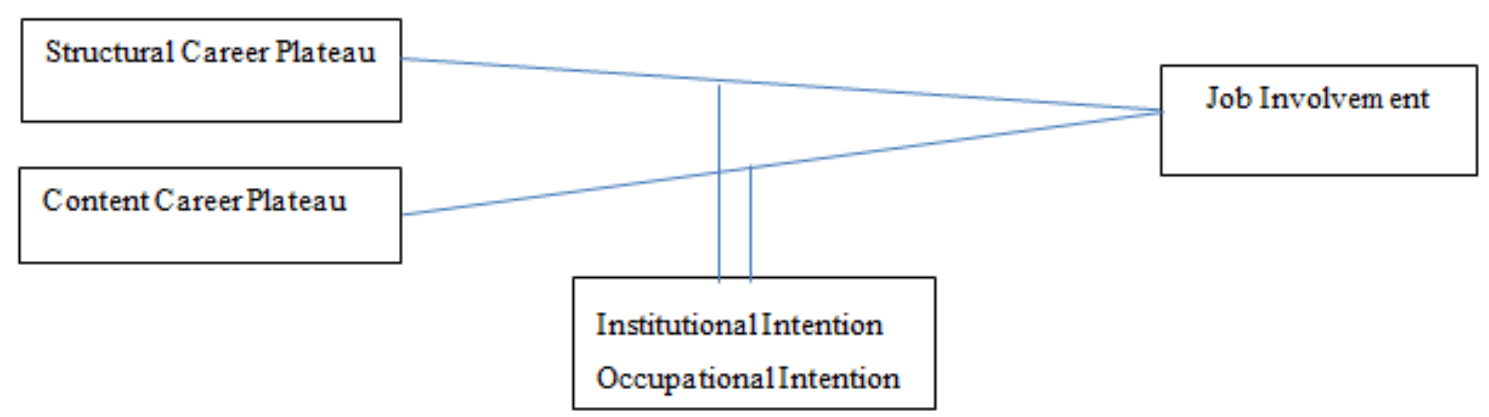

Figure 1. Model Proposed in this Study

Few empirical studies have examined potential moderators on the relationship between structural/content career plateau and work outcomes [21], especially in a military setting. To develop a model delineating the relationship of structural/content career plateau and job involvement, Figure 1 presents the theoretical framework of this study. Based on the different focuses on social value and work motivation, this study first explicitly extended the concepts of the structural/content career plateaus to military careers and examined whether the perception of structural/content career plateau will negatively related to job involvement. Next, we tested how institutional/occupational intention as a moderator to moderate relationship between the perception of structural/content career plateaus and job involvement and tried to clarify the moderation mechanism in theoretical and practical implications.

\section{Theory and Hypotheses}

\subsection{Perception of Structural/Content Career Plateaus}

Careers involve mobility paths of job ladders, where an individual travels through sequences of job positions within an organization. Because of the rapidly increasing number of downsizings and layoffs that characterizes today's work world, career plateauing or leveling off in a career path has been a topic of interest in the literature on career development for several decades. Over the years, the definition of career plateauing has evolved from a structural perspective to include content perspective. Two concepts of work-related plateaus have been identified. One concept is known as a structural career plateau, which is an assumption for the traditional model of career paths [20], and is defined as a point in one's career at which an individual perceives little chance of further vertical movement within an organization. The second concept is a theoretical extension, known as content career plateau, which occurs when an individual is no longer challenged by their job or job responsibility and has nothing new to learn, causing him to perceive stagnation in his career [11].

The nature of a structural plateau differs greatly from that of a content plateau. The previous study reported that the influence of job attitudes upon structural plateau and content plateau are different [1]. Regardless of whether an individual perceives a structural career plateau or a content plateau, he or she exhibits frustration with his/her future career and dissatisfaction with his/her current position. However, frustration or dissatisfaction is a subjective perception that is an interactive consequence of personal characteristics and workplace organizational environment.

\subsection{Job Involvement}

The concept of job involvement is often confused with job engagement. Job engagement is the energy and dedication an employee brings to his job and is the conceptual "opposite" of burnout. In simpler words, job engagement is a measure of the distribution percentage of individual resources (physiological and psychological) to the current job. In contrast, job involvement is defined as the degree to which an individual psychologically identifies with his or her work or the importance of work to his or her total self-image. Stoner \& Gallagher [24] integrated previous studies and indicated that job involvement involves cognitive preoccupation and concern with one's job, whereby individuals psychologically identify with work. Brown [2] concludes that a job-involved person is someone who (a) finds their job motivating and challenging, (b) is committed to both the specific job and the organization, without the inclination to consider leaving their position or organization, and (c) engages more closely in professional relationships and is more likely to receive feedback.

Highly involved employees, their jobs are connected with their identities, interests and life goals. Hence, this study assumed that job involvement in a military setting is a cognitive and emotional identification with military values and requires more extra efforts to achieve organizational goals.

\subsection{Perception of Structural/Content Career Plateaus and Job Involvement}

The military is typically a pyramid-shaped organization. Traditional military management emphasized paternalistic leadership, and military individuals must be educated to trust the leadership model, including in issues concerning career 
well-being. In the Taiwanese military, when high school students matriculate into the military university to be cadets, the majority are determined to adopt a military career as a long-term career. Due to organizational restructuring and personnel reductions, more career officers are competing for fewer promotions and developmental opportunities in their limited service career. Thus, an increasing number of career officers are experiencing structural or content career plateau, which they did not expect in the past. This is the perception of a gap in career expectancy. Nevertheless, the most important implication is that if these career officers cannot achieve a higher position or rank within the maximum service duration, they are forced to retire. Colloquially, among career officers, the perception of plateauing symbolizes an unpleasant barrier or an end to their military career. Overcoming a plateau makes the extension of their military career more likely.

The perception of potential career gaps for these officers is like a psychological contract violation, which occurs when one party in a relationship perceives the other's failing to fulfill the promised obligations [19]. Brown \& Leigh [3] indicated that an employee's perception of an organization as a psychologically safe and meaningful work environment is positively related to job involvement. In the military, officers are asked to make sacrifices, be dedicated, and submit to authority to fulfill the military's values or social expectations. When career officers face a lower probability of further promotion and are unable to extend their military careers, they are not only experiencing structural/content career plateaus but also losing the opportunity to self-actualize, leading to perceptions of unidentified and psychological contract violation. In this situation, an officer is prone to withdraw from his or her job and be less involved.

- Hypothesis 1a. The perception of structural career plateau is negatively related to job involvement.

- Hypothesis 1b. The perception of content career plateau is negatively related to job involvement.

\subsection{Institutional/Occupational Intentions}

After Moskos [14] claimed that the American military has moved from an institutional model toward an occupational model, the subject of institutional and occupational models has been frequently discussed in the literature related to military sociology. In fact, in addition to the military organization model, the development of military members' psychology has transitioned toward an occupational orientation $[15,16]$. Studies of the theme of the measurement for institutional/occupational intentions, however, show that these two modes are not conceptualized in terms of two ends of a continuum. Segal [23] suggested that the institutional and occupational constructs are independent dimensions rather than separate poles of the same dimension.

Institutional intention and occupational intention represent the terminal value reflecting employees' natural desire to actualize, develop, and grow at the workplace in different ways. The institutional intention of the military is based on military history, military sociology, and an emphasis on affectivity and solidarity [23]. An institution is legitimized in terms of institutional value, i.e., a purpose transcending individual self-interest in favor of a presumed higher good. Institutional-oriented career officers believe that national or social interests transcend self-interests, self-sacrifice is expected and deemed necessary to fulfill military tasks [15]. To achieve military tasks, self-sacrifice is necessary. They identify with subjecting to military discipline and law and an inability to resign, strike, or negotiate over working conditions to maintain military values. In the military institutional model, rank and seniority were valued more than professional skill [16].

In contrast to institutional intention, the occupational intention is rooted in individualism and utilitarianism [22]. An occupation is legitimized in terms of the marketplace, i.e., prevailing on monetary rewards for equivalent competencies [14]. The occupational model implies that priority is given to self-interest rather than the task itself or the employing organization; hence, employees usually enjoy rights to negotiate appropriate salary and work conditions. Career officers with occupational intention regard the military as a relationship between employees and an employer based upon a contract that defines the rights and responsibilities of both. Unlike those with institutional intentions, these officers regard the military as a workplace and military service as a job [12]. Career officers with an occupational intention believe that the market value for an employee should be based on his/her profession and skills, and insist that capability, performance, and contribution to the organization should be the key factors influencing their promotion and salary.

\subsection{Institutional/Occupational Intentions as Moderators}

We believed that the attitudes of institutional/occupational intention are induced by work value and motivation. A value reflects a belief about the desirability of a certain end-state, serving as a guiding principle for selecting or evaluating behavior, people, and events. Work value orientations prefer individual preferences over "ought standards". Work motivation is related to individual's interests, which often leads them to engage in behaviors related their interests. In organizational settings, an individual's motivation provides insight into their work-related reinforcement preferences. This study sought to interpret an implication for the moderator of institutional and occupational intention based on the aspects of the work value orientations and motivations.

Career officers who internalize organizational values regard their service to the country as a form of volunteerism. Cardador, Dane, \& Pratt [4] suggested such view was influenced by employees' institutional intention which 
made them intrinsically motivated. Indeed, one key component of military training is to instill institutional values in the service personnel. In fact, through the motto "Duty, Honor, Country", military universities encourage cadets to sacrifice and dedicate themselves to the nation to achieve the greater self and enjoy high esteem from the larger community as the security and pride of the country is often said to depend on their service. Career officers with institutional intention prioritize self-growth, altruistic behavior, and social interest rather than external rewards, such as gaining monetary rewards or advancing to a high position.

In view of the heightened sense of fulfilling institutional duties and ideals, we suggest that institutional intention moderates the relationship between structural/ content career plateaus and job involvement. Officers with high institutional intention will maintain their levels of job involvement even when facing structural/ content career plateaus. However, because of the weaker internalization of institutional values, officers with low institutional intention will be more sensitive to structural/ content career plateaus and react more negatively.

- Hypothesis 2a. Institutional intention moderates the negative relationship between the perception of structural career plateau and job involvement.

- Hypothesis 2b. Institutional intention moderates the negative relationship between the perception of content career plateau and job involvement.

Occupational intention is one value resulting from a mixture of competitive and individualistic orientations and presents a high level of payoff to the self. An individual prone to competitive or individualistic orientation would believe that others are also prone to competitive or individualistic orientation. Hence, occupational intention stresses extrinsic motivation and instrumental value, which reflects the traditional pursuit of success by advancing up the organizational hierarchy to achieve prestige, status, and high income. In an exchange relationship, the pursuit of self-interest drives individuals to seek information about formulating strategies to optimize their benefits or at the very least to achieve equality [26]. When the balance of exchange is not met, it invisibly will harm interpersonal relationships and hamper reciprocity behaviors.

As work is only viewed as a means to an end (i.e., prestige and salary), career officers with occupational intention are more likely to seek a balance between their inputs and returns [13]. In view of the heightened sense of pursuing professional self-interests, we suggest that occupational intention moderates the relationship between structural/content career plateaus and job involvement. Officers with higher occupational orientation will react more negatively in terms of job involvement when facing structural/content career plateaus.

- Hypothesis 3a. Occupational intention moderates the negative relationship between the perception of structural career plateau and job involvement.
- Hypothesis 3b. Occupational intention moderates the negative relationship between the perception of content career plateau and job involvement.

\section{Methods}

\subsection{Participants and Procedure}

This study was accomplished by collecting data from four different full-time training units for officers at the National Defense University (NDU) in Taiwan. Captains distributed 450 questionnaires at our request. To ensure confidentiality and to avoid ethical issues, we instructed the participants to seal the return envelope and send it back to the researchers directly. 365 were returned, and 338 were valid. The response rate was $75.11 \%$.

The final sample included 312 males and 26 females, 274 of whom were married. The mean age and military tenure of the sample were 35.53 years $(\mathrm{SD}=3.40)$ and 13.46 years $(\mathrm{SD}=3.22)$, respectively. The officers came from all four branches of the military, 107 samples came from branches of the Army, 36 from the Navy, 37 from the Air Force, and 158 from Military Headquarters. By rank, 258 were Majors, 69 were Lieutenant Colonels, and 11 were Colonels. In terms of civilian education, 168 held Bachelor's degrees and 170 earned Master's degrees or PhDs. With respect to military education, 101 had received an intermediate military education, 182 had received advanced training, and 55 had received further (strategic) military education.

\subsection{Measures}

\subsubsection{Perception of Structural/Content Career Plateaus}

Twelve items were used to measure perception of a structural/content career plateaus and were taken from Tammy, Joyce, Mark, \& Gregory [25]. Items were presented in five-point Likert format. Coefficients alpha for the structural/content career plateaus were .80 and .71 , respectively.

\subsubsection{Job Involvement}

The seventeen items were used to measure job involvement and were taken from Paullay, Alliger, \& Stone-Romero [18]. Items were presented in five-point Likert format. The coefficient alpha was .78.

\subsubsection{Institutional/Occupational Intentions}

Thirty items were used to measure the military institutional/occupational intentions and were taken from Chien [7]. There were 17 items for institutional intention and 13 items for occupational intention. Items were presented in five-point Likert format. Coefficients alpha for the institutional intention and the occupational intention were .78 and .73 , respectively. 


\subsubsection{Control Variables}

Previous literature indicated that demographic variables can affect the perception of career plateau and institutional/occupational intentions. We controlled for the respondents' gender, marital status, rank, military tenure, branch of service, job type, civil education level and military education level.

\section{Results}

Means, standard deviations, correlations, and coefficient alphas of all study variables are presented in Table 1 . We examined the hypotheses in several steps. First, all of the variables were mean-centered to avoid the influences of the collinearity effect. Next, ANOVA was employed to examine the correlation between the control variables and study variables. The correlated control variables together with the perception of structural/content career plateaus and institutional/occupational intentions predicted job involvement. As the results of ANOVA, we controlled for the respondents' gender, age, marital status, rank, military tenure, branch of service and education level to enter a hierarchical multiple regression to test Hypothesis 1 to Hypothesis 3. Thirdly, the control variables and study variables in turn entered the model to predict job involvement. Finally, the interaction of perceptions of structural/content career plateaus and institutional/occupational intentions were entered into the model. The results were presented in Table 2. Structural and content plateauing had a significantly negative influence on job involvement $(\beta=-.14, p=.01, \beta=-.17, p=.00)$. Thus, both $\mathrm{H} 1 \mathrm{a}$ and $\mathrm{H} 1 \mathrm{~b}$ were supported.

Next, the results of step 3 showed that the interaction of perceptions of the structural/content plateaus and institutional intention both had a significantly positive influence on job involvement $(\gamma=.72, \mathrm{p}=.00 ; \gamma=.31, \mathrm{p}=.04)$. Both $\mathrm{H} 2 \mathrm{a}$ and $\mathrm{H} 2 \mathrm{~b}$ were supported. As the interaction of perceptions of structural plateauing and occupational intention had a significantly negative influence on job involvement $(\gamma=-.35, p=.03)$, H3a was also supported. With respect to the relationship of the interaction of perceptions of the content plateauing and occupational intention, it was not a significant influence on job involvement $(\gamma=-.05$, $\mathrm{p}=.41$ ), and $\mathrm{H} 3 \mathrm{~b}$ was not supported.

\section{Discussion}

\subsection{Theoretical and Managerial Implications}

The current study advances the body of knowledge concerning institutional/occupational intention, the perception of career plateauing, and job involvement in several ways. First, previous studies have indicated that career plateaus are associated with negative organizational consequences. In the current study, we verified that the greater the perception of career plateauing, the less job involvement among career officers. However, due to rapid technological development, social tendencies, and concerns about the cost of military operation, military organizations have engaged in restructuring, and downsizing is an unavoidable policy during peacetime.

Moreover, because of an officer's shorter military career and the closed system of military, officers fear that the shortage of learning and challenging opportunities and the overall staleness of the job itself would increase the difficulty in the vertical movement within the military organization or in switching to another profession outside the military. This creates a favorable condition for career plateauing. Researchers have suggested management strategies to address negative impacts of the career plateau, such as providing supervisor support, job enrichment, and career counseling [9].

While, career plateau was found to be negatively related to job involvement, rather than advocating and framing military work as the fulfillment of a calling, the military management should rethink the problem of career plateauing and seek out effective management practices to reduce the negative impacts of lower job involvement. As $\mathrm{H} 2 \mathrm{a}$ and $\mathrm{H} 2 \mathrm{~b}$ predicted, one benefit attributed to higher institutional intention is that it can mitigate the negative consequences associated with plateauing among the career officers. When facing structural and content career plateau, officers with high institutional intention tended to handle it much better than officers with low institutional intention did. In contrast with institutional intention, occupational intention amplified the negative relationship between structural career plateau and job involvement. This interesting result provides a very important insight for understanding the behavior of military personnel.

As we observed the moderating effects of institutional/occupational intentions on the relationship between perceived career plateau and job involvement, we attempted to explain the results. First, people would explain motivation and behavior by external or internal attributions. Then, intentions are assumed to capture the motivational factors that influence the behavior of military personnel. Hence, intentions are the indications of how much of an effort individual are planning to exert, in order to perform the behavior. Second, we verified the moderating effect of institutional intention on the relationship between the perceived career plateauing and job involvement for Taiwanese career officers. Specifically, for a career officer with high institutional intention, a high perception of career plateauing is related to high job involvement. Institutional intention is a significant characteristic of military values. Scholars have indicated that a calling orientation is related positive organizational behavior, such as work motivation, job satisfaction, organizational commitment, organizational citizenship behavior, and low employee turnover and organizational attachment. The calling orientation is also an 
important component of self-regulation and a strong element of corporate cohesion.

Institutional intention is one value resulting from a mixture of an altruistic and prosocial orientations and yields a high level of payoff to others. An individual prone to altruistic or prosocial orientations would invest the more "trust" in others and make more concessions to achieve another's interest rather than self-interest. Institutional intention stresses on the intrinsic motivation and terminal value which reflect officers' natural desire to actualize, develop and grow. The officers with institutional intention prioritized self-growth rather than external rewards and tended to attribute the "career plateau" to their own limitations in "ability" and "effort". The setback of a career plateau could not stop these officers' belief in the greater value of their service in the military. In addition, content plateau is connected not only with the contents of the job, but also with whether the job enables employees to master new skills to enhance their employability and marketability, and ensures that employees remain professionally qualified and that they do not become obsolete in their profession. No matter which type of career plateaus encountered structural or content, which signified officers must restart their careers at this point. Hence, higher rates of institutional intention more significantly eased the negative consequences associated with career plateau associated with job involvement among the career officers. Hence, this study believes that it is beneficial to improve the overall quality of the military by arousing institutional intention or calling orientation.

Occupational intention focuses on extrinsic motivation and instrumental value, with a priority on maximum self-interest and visible rewards. The extrinsically oriented people tend to value prestige and salary, tend to view work as only a means to these ends, and tend to gravitate toward occupations and work assignments. Those officers with occupational intention tended to attribute the "career plateau" to the poor organizational circumstances. The career plateau setback could change their involvement to the military. Especially when they perceived structural plateauing, these officers endeavored to preserve their self-image or to seek other job opportunities offering greater salary, power, and status, even going so far as to withdraw from their military job. Hence, occupational intention fostered the negative consequences associated with the structural plateauing associated with job involvement among the career officers, especially those officers with high occupational intention.

In current study, a moderating effect of occupational intention was not found on the relationship between perceived content plateauing and job involvement. It is plausible that military leadership stressed rank and seniority more than professional skills, although prior scholars agreed that the military had switched the institutional model to occupational. Occupational intention reflects traditional subjective success instead of the pursuit of professional growth. 
Effect of Structural/Content Career Plateaus on Job Involvement:

Do Institutional/Occupational Intentions Matter?

Table 1. Means, Standard Deviations, Correlations and Coefficient Alphas among Study Variables

\begin{tabular}{|c|c|c|c|c|c|c|c|c|c|c|c|c|c|c|c|c|c|c|c|c|c|c|c|c|}
\hline Variables & $\mathrm{M}$ & SD & 1 & 2 & 3 & 4 & 5 & 6 & 7 & 8 & 9 & 10 & 11 & 12 & 13 & 14 & 15 & 16 & 17 & 18 & 19 & 20 & 21 & 22 \\
\hline 1.Gender ${ }^{a}$ & .54 & .27 & & & & & & & & & & & & & & & & & & & & & & \\
\hline 2.Marital status ${ }^{b}$ & .09 & .40 & $-.14^{* * *}$ & & & & & & & & & & & & & & & & & & & & & \\
\hline 3.Majors ${ }^{c}$ & .77 & .43 & .03 & -.09 & & & & & & & & & & & & & & & & & & & & \\
\hline 4.Lieutenant ${ }^{c}$ & .20 & .40 & -.01 & .08 & $-.91^{* *}$ & & & & & & & & & & & & & & & & & & & \\
\hline 5.Colonels ${ }^{c}$ & .03 & .18 & -.05 & .05 & $-.33^{* *}$ & -.09 & & & & & & & & & & & & & & & & & & \\
\hline 6. Army ${ }^{d}$ & .32 & .47 & $-.13^{*}$ & -.06 & $.18^{* *}$ & $-.16^{*}$ & -.09 & & & & & & & & & & & & & & & & & \\
\hline 7. Navy $^{d}$ & .11 & .31 & -.06 & $.14^{* *}$ & .01 & -.03 & .05 & $-.24^{* *}$ & & & & & & & & & & & & & & & & \\
\hline 8. Air Force ${ }^{d}$ & .11 & .31 & -.03 & .00 & $-.14^{*}$ & .03 & $.26^{*}$ & $-.24^{* *}$ & $-.12^{*}$ & & & & & & & & & & & & & & & \\
\hline 9. Headquarters ${ }^{d}$ & .47 & .50 & $.18^{* * *}$ & -.03 & -.09 & $.14^{* *}$ & -.11 & $-.64^{* *}$ & $-.32^{* *}$ & $-.33^{* *}$ & & & & & & & & & & & & & & \\
\hline 10. Job type ${ }^{e}$ & .77 & .50 & $.14^{*}$ & .01 & $-.13^{*}$ & $.12^{*}$ & .04 & $-.29^{* *}$ & .10 & .08 & $.16^{* *}$ & & & & & & & & & & & & & \\
\hline $\begin{array}{l}\text { 11. Civil education } \\
\text { levef }\end{array}$ & .79 & .50 & .02 & .00 & $-.14^{*}$ & .11 & .08 & $-.19^{* * *}$ & .02 & $.12^{*}$ & .09 & .07 & & & & & & & & & & & & \\
\hline 12. Basic level ${ }^{g}$ & .01 & .08 & -.02 & -.06 & .04 & -.04 & -.01 & -.05 & .10 & -.03 & .01 & -.01 & .08 & & & & & & & & & & & \\
\hline $\begin{array}{c}\text { 13.Intermediate } \\
\text { level }^{g}\end{array}$ & .30 & .46 & -.02 & -.07 & $.27^{* *}$ & $-.23^{* *}$ & $-.12^{*}$ & -.10 & .07 & .02 & .03 & -.05 & $.58^{* *}$ & -.05 & & & & & & & & & & \\
\hline $\begin{array}{l}\text { 14. Advanced level } \\
g\end{array}$ & .54 & .50 & .00 & .02 & $.32^{* *}$ & $-.25^{*}$ & -.20 & $.21^{* *}$ & -.10 & $-.13^{*}$ & -.06 & .00 & $-.59^{* *}$ & -.08 & $-.70^{* * *}$ & & & & & & & & & \\
\hline 15. Further level ${ }^{g}$ & .16 & .37 & .02 & .07 & $-.78^{* *}$ & $.63^{* *}$ & $.42^{*}$ & $-.16^{* *}$ & .03 & $.15^{* *}$ & .04 & .06 & .07 & -.03 & $-.29^{* *}$ & $-.47^{* *}$ & & & & & & & & \\
\hline 16. Age & 35.53 & 3.40 & .10 & .12 & $-.67^{* *}$ & $.49^{* *}$ & $.50^{* *}$ & $-.21^{* *}$ & .07 & $.21^{* *}$ & .02 & $.20^{* *}$ & $.13^{*}$ & -.04 & $-.24^{* *}$ & $-.29^{* *}$ & $.69^{* *}$ & & & & & & & \\
\hline 17. Military tenure & 13.46 & 3.22 & .01 & $.14^{*}$ & $-.75^{* *}$ & $.57^{* *}$ & $.50^{* *}$ & $-.18^{* *}$ & .06 & $.21^{* *}$ & .00 & $.15^{* *}$ & .09 & -.07 & $-.28^{* * *}$ & $-.28^{* *}$ & $.74^{* *}$ & $.91^{* *}$ & & & & & & \\
\hline $\begin{array}{l}\text { 18. Occupational } \\
\text { intention }\end{array}$ & 4.05 & .59 & $-.11^{*}$ & $.14^{* *}$ & .03 & .02 & $-.12^{*}$ & .03 & .01 & $-.14^{*}$ & .05 & -.02 & -.04 & .05 & -.01 & .07 & -.09 & -.09 & -.04 & (.73) & & & & \\
\hline $\begin{array}{l}\text { 19. Institutional } \\
\text { intention }\end{array}$ & 3.12 & .62 & .01 & -.06 & .01 & .00 & -.03 & -.06 & -.01 & .02 & .05 & -.02 & -.10 & -.03 & .01 & -.00 & -.01 & -.04 & -.01 & -.08 & $(.78)$ & & & \\
\hline $\begin{array}{c}\text { 20. Structural } \\
\text { plateauing }\end{array}$ & 3.14 & .84 & .05 & .04 & -.09 & .08 & .03 & $-.15^{* *}$ & .03 & .08 & .07 & .09 & .08 & -.09 & .07 & -.09 & .05 & .09 & $.13^{*}$ & -.01 & .05 & $(.80)$ & & \\
\hline $\begin{array}{c}\text { 21. Content } \\
\text { plateauing }\end{array}$ & 4.00 & .54 & -.05 & .00 & -.03 & .05 & -.04 & -.00 & .00 & -.05 & .03 & -.03 & -.02 & -.05 & .03 & -.02 & .00 & .02 & .02 & $-.18^{* *}$ & $.11^{*}$ & -.11 & $(.71)$ & \\
\hline 22.Job involvement & 3.17 & .47 & -.02 & -.03 & $-.13^{*}$ & .10 & .10 & -.03 & -.10 & $.13^{*}$ & .00 & -.09 & $-.11^{*}$ & -.01 & $-.17^{* *}$ & .04 & $.15^{* *}$ & $.18^{* *}$ & $.21^{* *}$ & -.01 & $.40^{* *}$ & $-.12^{*}$ & $-.13^{*}$ & $(.78)$ \\
\hline
\end{tabular}

Note. $\mathrm{N}=338$. (Cronbach's alpha coefficients are presented on the diagonal), $* * \mathrm{p}<.01 . * \mathrm{p}<.05$.

a. Gender was coded as $0=$ men and $1=$ women.

b. Marital status was coded as $0=$ unmarried and $1=$ married.

c. Rank was coded as $(1,0,0)=$ Majors, $(0,1,0)=$ Lieutenant Colonels and $(0,0,1)=$ Colonels

d. Branch of service was coded as $(1,0,0,0)=$ Army, $(0,1,0,0)=$ Navy, $(0,0,1,0)=$ Air Force, $(0,0,0,1)=$ others (including from military headquarters and military instructors at senior high schools or universities.)

e. Job type was coded as $0=$ full-time or stand-by combat troops and $1=$ executive divisions with fixed working hours.

f. Civil education level was coded as $0=$ Bachelors' degrees and $1=$ Masters' degrees or Ph.Ds.

g. Military education level was coded as $(1,0,0,0)=$ basic military education, $(0,1,0,0)=$ intermediate military education, $(0,0,1,0)=$ advanced training $($ command and staff level) and $(0,0,0,1)=$ further $($ strategic $)$ military education. 
Table 2. Hierarchical Multiple Regression Results

\begin{tabular}{|c|c|c|c|c|c|c|}
\hline Dependent variable & \multicolumn{6}{|c|}{ Job involvement } \\
\hline Step 1 & $\beta$ & $\mathrm{P}$ & $\beta$ & $\mathrm{p}$ & $\beta$ & $\mathrm{p}$ \\
\hline Gender & -.04 & .46 & -.05 & .35 & -.04 & .46 \\
\hline Age & .06 & .50 & .08 & .49 & -.01 & .92 \\
\hline Marital status & -.07 & .22 & -.04 & .42 & -.07 & .19 \\
\hline Rank & .02 & .80 & -.10 & .28 & -.10 & .33 \\
\hline Military tenure & .12 & .19 & .20 & .13 & .28 & .06 \\
\hline Branch of service & .04 & .45 & .02 & .73 & .06 & .32 \\
\hline Civil education level & -.09 & .18 & -.06 & .36 & -.10 & .16 \\
\hline Military education level & .09 & .32 & .08 & .28 & .07 & .41 \\
\hline \multicolumn{7}{|l|}{ Step 2} \\
\hline Institutional intention & & & .34 & .00 & & \\
\hline Occupational intention & & & -.11 & .05 & & \\
\hline Structural career plateauing & & & -.14 & .01 & -.52 & .16 \\
\hline Content career plateauing & & & -.17 & .00 & -.16 & .57 \\
\hline \multicolumn{7}{|l|}{ Step 3} \\
\hline $\begin{array}{l}\text { Structural career plateauing } \times \\
\text { Institutional intention }\end{array}$ & & & & & .72 & .00 \\
\hline $\begin{array}{c}\text { Structural career plateauing } \times \\
\text { Occupational intention }\end{array}$ & & & & & -.35 & .03 \\
\hline $\begin{array}{l}\text { Content career plateauing } \times \\
\text { Institutional intention }\end{array}$ & & & & & .31 & .04 \\
\hline $\begin{array}{c}\text { Content career plateauing } \times \\
\text { Occupational intention }\end{array}$ & & & & & -.05 & .41 \\
\hline $\mathrm{R}^{2}$ & \multicolumn{2}{|c|}{.06} & \multicolumn{2}{|c|}{.26} & \multicolumn{2}{|c|}{.08} \\
\hline F-Value & \multicolumn{2}{|c|}{2.43} & \multicolumn{2}{|c|}{10.22} & \multicolumn{2}{|c|}{2.51} \\
\hline
\end{tabular}

\subsection{Limitations and Directions for Future Research}

This study is not without limitations. First, a major limitation was the commonality of the participants. Considering the study objective and to represent the Taiwanese military, we selected National Defense University trainees for as our sample population. However, all the participants were trainees who were recommended by their unit and passed the entrance examination and therefore particularly high-achieving among officers of the same rank in their unit. They would therefore attain more opportunities for career advancement than others. Thus, our findings may not be able to be generalized to all military personnel. Future research should include lower ranks of military personnel or even the compulsory officers and volunteer soldiers in Taiwan.

Next, our study used a self-report methodology, which may yield a common method variance (CMV) bias. Although we have taken measures to reduce CMV bias, we suggest that future studies use different sources (i.e., military personnel and their supervisors) or adopt a longitudinal design to measure the relationship between long-term effects of structural/content career plateaus on job involvement.

Thirdly, the military has a long history of cultivating famous leaders in the military, enterprises, government departments, and academia. Traditionally, military education has been a successful paradigm. Notably, certain characteristics of career officers meet the demands of civil organizations. Hence, this study boldly assumed the feasibility of promoting institutional intention or institutional motivation in civil organizations. Future studies should examine the relationship between institutional intention and other individual or organizational variables in civil organizations, such as employee attitudes and behaviors and organizational climate and enhance the applicability of institutional intention and motivation.

Finally, it is unavoidable that the military model has moved toward an occupational model. Future research to examine the relationship between occupational intention and relevant work attitude is important for military management. Even more importantly, more effective moderating variables should be identified to reduce the negative consequence of the relationship between the perception of career plateauing and work-related consequences.

\section{REFERENCES}

[1] Allen, T.D., Russell, J.E.A., Poteet, M.L., \& Dobbins, G. H. (1999). Learning and development factors related to 
perceptions of job content and hierarchical plateauing. Journal of Organizational Behavior, 20,7, 1113.

[2] Brown, S. P. (1996). A meta-analysis and review of organizational research on job involvement. Psychological Bulletin, 120, 235-55.

[3] Brown, S. P., \& Leigh, T. W. (1996). A new look at psychological climate and its relationship to job involvement, effort, and performance. Journal of Applied Psychology, 81, 358-368.

[4] Cardador, M. T., Dane, E., \& Pratt, M. G. (2011). Linking calling orientations to organizational attachment via organizational instrumentality. Journal of Vocational Behavior, 79, 2, 367-378.

[5] Cheng, J. W., \& Su, T. W. (2013). Career plateauing and institutional/occupational intention for Taiwanese career officers. Military Psychology, 25, 2, 156-165.

[6] Cheng, J. W., Seih, Y. T., Hung, C. Z., \& Su, T. W. (2016). Voice behavior and career success: The moderating role of supervisor attribution motives, Universal Journal of Psychology, 4, 4, 209-214.

[7] Chien, S. F. (2003). Theoretical modification and validity verification of the I/O modalities applied for R.O.C. volunteer officers. The NCCU Journal of Sociology, 34, $37-77$.

[8] Hobfoll, S. E., Vinokur, A. D., Pierce, P. F., \& Lewandowski-Romps, L. (2012). The combined stress of family life, work and war in Air Force men and women: A test of conservation of resources theory. International Journal of Stress Management, 19, 3, 217-237.

[9] Ismail, M. (2008). Career plateau constructs, consequences and coping strategies. European Journal of Social Sciences, $5,4,111-120$.

[10] Lemire, L., Saba, T., \& Gagnon, Y. (1999). Managing career plateauing in the Quebec public sector. Public Personnel Management, 28, 375-391.

[11] Lentz, E. \& Allen, T. D. (2009). The role of mentoring others in the career plateauing phenomenon", Group \& Organizational Management, 34, 3, 358-384.

[12] Levy, Y. (2007). Soldier as laborers: A theoretical model. Theory and Society, 36, 187-208.

[13] Marshburn, T. H., \& Rollin, S. A. (2005). The motivational orientation of army aviators. Military Psychology, 17(2), 69-87.

[14] Moskos, C. C. (1977). From institution to occupation: Trends in military organization. Armed Forces and Society, 4, $1,41-50$.
[15] Moskos, C. C. (1986). Institutional, occupational trends in armed forces: An update. Armed Forces and Society, 12, 3, 377-382.

[16] Moskos, C. C., \& Wood, F. R. (1988). The military: More than just a job? London, UK: Brassey's Defense Publishers.

[17] Nachbagauer, A. G. M., \& Riedl, G. (2002). Effects of concepts of career plateaus on performance, work satisfaction and commitment. International Journal of Manpower, 23, 8, 716-733.

[18] Paullay, I., Alliger, G., \& Stone-Romero, E. (1994). Construct validation of two instruments designed to measure job involvement and work centrality. Journal of Applied Psychology, 79, 224-228.

[19] Robinson, S. L., Kraatz, M. S., \& Rousseau, D. M. (1994). Changing obligations and the psychological contract: A longitudinal study. Academy of Management Journal, 37, 137-152.

[20] Rotondo, D. M., \& Perrewe, P. L. (2000). Coping with a career plateau: An empirical examination of what works and what doesn't. Journal of Applied Social Psychology, 30, 2622-2646

[21] Salami, O. S. (2010). Career plateauing and work attitudes: Moderating effects of mentoring others with Nigerian employees. Europe's Journal of Psychology, 6, 4, 71-92.

[22] Segal, D. R., \& Segal, M. W. (1983). Change in military organization. Annual Review of Sociology, 9, 151-170

[23] Segal, D. R. (1986). Measuring the institutional/occupational change thesis. Armed Forces and Society, 12, 3, 351-376.

[24] Stoner, J. S., \& Gallagher, V. C. (2010). Who Cares? The role of job involvement in psychological contract violation. Journal of Applied Social Psychology, 40, 6, 1490-1514.

[25] Tammy D. A., Joyce, E. A. R., Mark, L. P., \& Gregory, H. D. (1999). Learning and development factors related to perceptions of job content and hierarchical plateauing. Journal of Organizational Behavior, 20, 7, 1113-1137.

[26] Van Kleef, G. A., \& De Dreu, C. K. W. (2002). Social value orientation and impression formation: A test of two competing hypotheses about information search in negotiation. The International Journal of Conflict Management, 13, 1, 59-77.

[27] Xie, B.G. Lu, X. X. \& Zhou, W. X. (2015). Does double plateau always lead to turnover intention? Evidence from China with indigenous career plateau scale. Journal of Career Development, 42, 6, 540-553. 